\begin{tabular}{|l|l|l|}
\hline \multicolumn{2}{|c|}{ PublisherInfo } \\
\hline \hline PublisherName & $:$ & BioMed Central \\
\hline \hline PublisherLocation & $:$ & London \\
\hline \hline PublisherImprintName & $:$ & BioMed Central \\
\hline \hline
\end{tabular}

\title{
Forty million years of solitude
}

\begin{tabular}{|l|l|l||}
\hline \multicolumn{2}{|c|}{ ArticleInfo } \\
\hline \hline ArticleID & $:$ & 3689 \\
\hline \hline ArticleDOI & $:$ & $10.1186 /$ gb-spotlight-20000526-01 \\
\hline \hline ArticleCitationID & $:$ & spotlight-20000526-01 \\
\hline \hline ArticleSequenceNumber & $:$ & 126 \\
\hline \hline ArticleCategory & $:$ & Research news \\
\hline \hline ArticleFirstPage & $:$ & 1 \\
\hline \hline ArticleLastPage & $:$ & 2 \\
\hline \hline & & RegistrationDate : 2000-05-26 \\
ArticleHistory & $:$ & OnlineDate $\quad 2000-05-26$ \\
\hline \hline ArticleCopyright & $:$ & BioMed Central Ltd2000 \\
\hline \hline ArticleGrants & $:$ & \\
\hline \hline ArticleContext & $:$ & 130591111 \\
\hline \hline
\end{tabular}




\section{William Wells}

Email:wells@biotext.com

The loss of sexual reproduction is seen as an evolutionary dead end, but researchers have seen no sign of sex in the four families, 18 genera and 360 species of the class Bdelloidea. In the 19 May Science, Welch and Meselson analyze the DNA sequences of bdelloids and report that these tiny protostomes have, indeed, survived without sex (Science 2000, 288:1211-1215). Asexual reproduction with no exchange between non-sister chromosomes has created a telltale and extreme sequence divergence (up to $50 \%$ for degenerate positions) between the two alleles in a single organism. The hunt is now on for further signs of asexuality - such as the disabling of genes for spermatogenesis and meiosis - and for clues as to how bdelloids resist mutagenesis and parasites without the genome shuffling that comes with sex.

\section{References}

1. Science, [http://www.sciencemag.org/]

2. Evolution: contemplating life without sex. 